\title{
Air movement, gender and risk of sick building syndrome headache among employees in a Jakarta office
}

\author{
Margaretha Winarti", Bastaman Basuki ${ }^{\dagger}$, Abdulbar Hamid ${ }^{\ddagger}$
}

\begin{abstract}
Abstrak
Gedung-gedung perkantoran umumnya dilengkapi dengan sistim sirkulasi udara atau pendingin secara buatan untuk menciptakan kondisi lingkungan kerja yang nyaman. Namun, masih terdapat gejala-gejala sindrom gedung sakit (SGS). Salah satu gejala SGS adalah nyeri kepala SGS (NK SGS) Oleh karena itu perlu dikaji diidentifikasi faktor-faktor risiko terhadap timbulnya NK SGS. Kasus dan kontrol diidentifikasi melalui survei terhadap seluruh pekerja di kantor tersebut pada bulan Mei - Agustus 2002 di suatu perkantoran di Jakarta. Kasus adalah subjek dengan NK SGS, kontrol adalah subjek tanpa keluhan NK SGS selama satu bulan terakhir. Subjek penelitian berjumlah 240 orang, dan yang menderita NK SGS sebanyak 36 orang (15\%). Bila dibandingkan dengan kecepatan gerakan udara yang normal, maka kecepatan gerakan udara yang cepat memperkecil risiko timbulnya NK SGS sebesar 57\% [(rasio odds (OR) suaian $=0,43 ;$ 95\% interval kepercayaan (CI): 0,19-0,95]. Bila dibandingkan dengan pekerja laki-laki, pekerja perempuan mempunyai risiko NK SGS hampir 3 kali lipat lebih besar (OR suaian =2,96; 95\% CI: 1,29-6.75). Pekerja dengan kebiasaan kadang-kadang sarapan, mempunyai risiko terkena NK SGS lebih kecil dibandingkan dengan yang biasa sarapan (OR suaian $=0.27 ;$ 95\% CI: 0,10-0,96). Faktor suhu, kelembaban dan kebiasaan merokok tidak terbukti berkaitan dengan NK SGS. Pegawai perempuan mempunyai risiko NK SGS jika dibandingkan dengan laki-laki. Di samping itu, kecepatan gerakan udara yang lambat mempertinggi risiko NK SGS. Oleh karena itu perlu menambah kecepatan gerakan udara untuk mengurangi risiko timbulnya NK SGS terutama terhadap tempat kerja perempuan. (Med J Indones 2003; 12: 171-7)
\end{abstract}

\begin{abstract}
Even though office buildings are usually equipped with ventilation system or air conditioning to create a comfortable working environment, yet there is still found a number of sick building syndrome (SBS) symptoms. One of the symptoms of SBS is SBS headache. Therefore, it is crucial to identify risk factors related to SBS headache. Cases were subjects who have suffered SBS headache, and controls were subjects who did not suffered headache for the last one month. Cases and controls were selected through a survey on all of employees in the said office during the period of May to August 2002. Total respondents were 240 employees including 36 people suffered SBS headache (15\%). Compared to the normal air movement, faster air movement decreased the risk of SBS headache by $57 \%$ [adjusted odds ratio $(O R)=0.43 ; 95 \%$ confidence intervals (CI): 0.19-0.95]. Female employees, compared to the males ones, had a higher risk of getting SBS headache by almost three times (adjusted OR $=2.96: 95 \%$ CI: 1.29-6.75). Employees who had breakfast irregularly, had a lower risk to SBS headache than those who have breakfast regularly (adjusted OR=0.31; $95 \%$ CI: 0.09-0.84). Temperature, humidity and smoking habits were not noted correlated to SBS headache. Female workers had greater risk of suffering SBS headache. In addition slower air movement increased the risk of SBS headache. Therefore, it is recommended to improve the progress of air in order to reduce the risk of SBS headache, especially for female workplace. (Med I Indones 2003; 12: 171-7)
\end{abstract}

Keywords: sick building syndrome headache, gender, air movement

Tall buildings are usually closed structures, which are equipped and circulated with air conditioning system

- Medical Officer, Pi-...rarta Lloyd, Jakarta, Indonesia

+ Department of Community Medicine, Faculty of Medicine, University of Indonesia, Jakarta. Indonesia

Department of Neurology, Faculty of Medicine, University of Indonesia / Dr. Cipto Mangunkasumo Hospital. Jakarta, Indonesia in order to create a comfortable working condition for its occupants. ${ }^{1-3}$ Comfortable working condition will have an effect on working productivity. A 1984 telephone survey of 600 office workers in the United States estimated that their productivities were hampered by poor Indoor Air Quality (IAQ). ${ }^{2-3}$

Inadequate IAQ will cause discomfort phenomenon and medical symptoms to building occupants such as sick building syndrome (SBS), building-related illness 
(BRI), Legionnaires' disease, Pontiac fever, et cetera. ${ }^{1-4}$ One of SBS symptoms that often found in the workplace is headache. ${ }^{1-5}$ Previous study associated headache with absenteeism, increasing medical costs, productivity loss, and decreased work quality. ${ }^{6}$ However, no study has investigated the relationship between SBS headache and physical factors of IAQ among office workers. This paper presents the prevalence of SBS headache among workers and SBS headache related risk factors in particular air movement, temperature, humidity and gender.

\section{METHODS}

The study was in a four-storey office building in Jakarta. Subjects of this study were administration, computing, and non-skilled workers who had worked in the building for at least 1 year, and not having respiratory tract infection. Data collection was done by first author and a medical doctor every working day from $8.00 \mathrm{AM}$ to $5.00 \mathrm{PM}$ during the period of May to August 2002

Data was collected by interviewing and physical examination the subjects. Air quality measurements were performed at the work sites. Interviews based on two questionnaires. The first questionnaire regarding demography characteristics, psycho-social factors, convenience of workplace, eating, sleeping and smoking habits, nutrition status, precipitating factors (medical, surgical, family, and allergy history), and usage of medicines. The second questionnaire was designed specifically to find data of headache and other symptoms of SBS.

Air quality measurements within working environment consisted of air movement, temperature and humidity. We have used Metrosonics heat stress monitor (recent calibrated September 2001) and Sibata-psychrometer (recent calibrated September 2001) for dry/wet bulb air temperature, air movement; and air humidity measurement, respectively. First of all, one measurement spot of most poor IAQ was determined. Then, it was measured every hour, starting from 9.00 AM up till 5.00 PM to get the peak time of the worst air quality. Furthermore, measurement continued to other spots, once each, according to the peak time.

Air movement is stated in meter per second. Air temperatures measured with dry bulb temperature $(\mathrm{db})$ using Celsius scale. Relative humidity $(\mathrm{RH})$ is stated in percentage ${ }^{7}$ to express the amount of moisture in a given sample of air in comparison with the amount of moisture the air would hold if totally saturated at the temperature of the sample.

The SBS headache case was defined as the worker who suffered headache for the last one month and fulfill the following criteria: occurred during working hours in the office building at least twice a week, followed by one or more symptoms in the concurring two to four weeks, which then gradually disappear after leaving the building, and re-emerge once they are back at work in the building. ${ }^{2,4,8}$ The control was worker who have never suffered any type of headache for the last one month.

Socio-demographic characteristic factors consisted of age and gender. Work characteristic factors: workload, working tenure, length of work in the office building (hour per day), number of working days per week, number of people per working space. Breakfast and smoking habit factors.

Prior to the study subjects were informed about the objective, procedure, and benefit of the study, in addition that confidentiality would be guaranteed. Subjects signed the informed consent document.

For this analysis, risk factors and subject characteristics were classified as follow: Age (19-29, 30-39, 40-49, 50-57 years); gender (male, female); type of work in the last 1 month (administration, computing, nonskilled work); occupation (staffs/clerks, sub-unit head, unit head, division head). Workload classification based on the quality and quantity work speed, and we categorized into three groups: light, moderate, and heavy. Those who had light workload such as secretary and office boy; moderate workload such as research and development, internal control personnel; heavy workload such as accounting, traffic and marketing personnel who has to monitor the ships movements around the clock.

Average length of work per day $(8,9-10,10$ hours or more). Worker density is working area per worker $\left(34-60,16-33,6-15 \mathrm{~m}^{2}\right)$. Body mass index, based on Ministry of Health of Indonesia grouping (1966) consisted of four subgroups (lack of nutrition $=<$ 18.5 , normal $=18.5-24.9$, overweight $=25.0-27.0$, obese $=27.1$ or more). Smoking habit in the past 3 months (never smoked, past smoker, current smoker). 
Temperature, humidity, and air movement were classified as suggested by Ministry of Manpower of the Republic of Indonesia (1978) as followed. Temperature (comfort $=21^{\circ}-30^{\circ} \mathrm{C}$, warm $=>30^{\circ} \mathrm{C}$ ); humidity (normal $=65-95 \%$, low $=<65 \%$ ); air movement (fast $=>0,2 \mathrm{~m} / \mathrm{second}$, slow $=<0.005$ $\mathrm{m} / \mathrm{second}^{3}$. $^{3}$

\section{Statistical analysis}

Statistical analyses were done using STATA 6.0 software. ${ }^{9}$ A number of risk factors were examined whether they were potential confounders and/or effect modifiers. Unconditional logistic regression analysis ${ }^{10}$ was used in order to determine the confounding effects and to determine the risk factors for hypertension. A risk factor was considered to be a potential confounder if in the univariate test it had a $P$-value $<$ 0.25 which would be considered as a candidate for the multivariate model along with all known risk factors for hypertension. ${ }^{11}$ Confounders were estimated by the method of maximum likelihood. Ninety-five percent confidence intervals were based on the standard error of coefficient estimates. Relative risks represented by odds ratios (OR) were estimated by the methods of maximum likelihood.

\section{RESULTS .}

The office employees working at that office were 292 . A number of 42 employees were not eligible to be sampled since they were not working in the head office. In addition, 10 employees were excluded since they worked in the office for less than 1 month, or have respiratory tract infection, or other illness that cause headache, or absent during the medical assessment, or not willing to participate in this survey. As a result, the total respondents become 240 people.

The medical findings showed that 56 employees had unclassified headache, and another 26 employees suffered other types of headache (e.g.: migraine, tension-muscle and/or mixed of both). Subjects suffering from these 2 types of headache were excluded from the analysis. This leaved 36 subjects $(15 \%)$ who suffered SBS headache and 122 people who did not suffer any headache.

The air measurements at the workplace ranged from 0.13 until $0.53 \mathrm{~m}$ per second, temperature ranged from $23.0^{\circ}$ to $31.0^{\circ}$ Celsius, and humidity level was ranged from 46.5 to $81.0 \%$.

Table 1 exhibits that the age of employees ranges from 19 to 57 years. The majority of employees was

Table 1. Age, smoking habits and risk of sick building headache

\begin{tabular}{|c|c|c|c|c|c|c|c|}
\hline & \multicolumn{4}{|c|}{ Sick building headache } & \multirow{3}{*}{$\begin{array}{c}\text { Crude } \\
\text { odds ratio }\end{array}$} & \multirow{3}{*}{$\begin{array}{c}95 \% \\
\text { confidence } \\
\text { intervals }\end{array}$} & \multirow{3}{*}{$\mathrm{p}$} \\
\hline & \multicolumn{2}{|c|}{$\begin{array}{c}\text { Absent } \\
(\mathrm{N}=122)\end{array}$} & \multicolumn{2}{|c|}{$\begin{array}{l}\text { Present } \\
(\mathrm{N}=36)\end{array}$} & & & \\
\hline & $\mathrm{n}$ & $\%$ & $\mathrm{n}$ & $\%$ & & & \\
\hline \multicolumn{8}{|l|}{ Age group (years) } \\
\hline $19-29$ & 20 & 16.4 & 7 & 19.4 & 1.00 & Referent & \\
\hline $30-39$ & 42 & 34.4 & 20 & 55.6 & 1.36 & $0.49-3.74$ & $0.55 \mathrm{I}$ \\
\hline $40-49$ & 32 & 26.2 & 5 & 13.9 & 0.45 & $0.12-1.60$ & 0.216 \\
\hline $50-57$ & 28 & 23.0 & 4 & 11.1 & 0.41 & $0.11-1.59$ & 0.195 \\
\hline \multicolumn{8}{|l|}{ Smoking habits } \\
\hline Non smoker & 50 & 41.0 & 18 & 50.0 & 1.00 & Referent & \\
\hline Mild smoker & 53 & 43.4 & 14 & 38.9 & 0.73 & $0.33-1.63$ & 0.447 \\
\hline Moderate smoker & 14 & 11.5 & 3 & 8.3 & 0.59 & $0.15-2.31$ & 0.454 \\
\hline Heavy smoker & 5 & 4.1 & 1 & 2.8 & 0.55 & $0.06-5.08$ & 0.603 \\
\hline \multicolumn{8}{|l|}{ Temperature } \\
\hline Comfortable & 14 & 11.5 & 4 & 11.1 & 1.00 & Referent & \\
\hline Warm & 108 & 88.5 & 32 & 88.9 & 1.04 & $0.32-3.37$ & 0.952 \\
\hline \multicolumn{8}{|l|}{ Humidity } \\
\hline Normal & 19 & 15.6 & 3 & 8.3 & 1.00 & Referent & \\
\hline Low & 103 & 84.4 & 33 & 91.7 & 2.03 & $0.56-7.29$ & 0.278 \\
\hline \multicolumn{8}{|c|}{ Working space per person $\left(\mathrm{m}^{2}\right)$} \\
\hline $34-60$ & 13 & 10.7 & 3 & 8.3 & 1.00 & Referent & \\
\hline $16-33$ & 19 & 15.6 & 2 & 5.6 & 0.46 & $0.07-3.12$ & 0.424 \\
\hline $6-15$ & 90 & 73.8 & 31 & 86.1 & 1.49 & $0.40-5.59$ & 0.552 \\
\hline
\end{tabular}


males. Age group and smoking habit did not correlated with the risk of SBS headache symptom. Compared to the age group of $19-29$ years, the older employees of $30-39$ and $40-57$ years had moderately higher risk exposure to SBS headache symptom. The temperature, humidity, and employees density were noted not to instigate the risk of SBS headache.

Table 2 shows that job position, occupation factor, number of working days per week, and number of working hours per day were verified not to trigger SBS headache. However, workload had a moderate correlation with SBS headache. In addition, those who had smoking habits had a moderate lower risk of SBS headache relative to non smokers.

The final model (Table 3 ) demonstrates that from the air movement point of view, employees who worked in an area with fast air movement has a lower risk of SBS headache by $57 \%$ (adjusted odd ratio 0.43 ) compared with the employees who worked in an area with slow air movement. In addition, from the gender point of view, female workers had almost three times higher risk of having SBS headache compared to male ones.
Furthermore, the breakfast habit observance showed that employees who had irregular breakfast had lower risk of getting SBS headache by $69 \%$ (adjusted odd ratio 0.31 ) relative to those who had regular breakfast. Nevertheless, the employees who did not have breakfast habit had a moderately low risk (adjusted odd ratio 0.35 ).

\section{DISCUSSION}

There are some limitations in this study. Subjects of this study came from limited population. The results of the study would illustrate the condition of the said population or other similar population. In addition, there might be recall bias exist. In order to eliminate the this constraint, the study used a standardized form, and interviews were conducted by the first author and a doctors who were specifically trained for this study.

This study found the prevalence of SBS headache of $15 \%$. A number of SBS headache occurred during the survey was higher than the previous study in Singapore. ${ }^{12}$ This might be due to several differences in respondents' characteristics and better air flow in the working environment in Singaporean office buildings.

Table 2. Position, working load and risk of sick building headache

\begin{tabular}{|c|c|c|c|c|c|c|c|}
\hline & \multicolumn{4}{|c|}{ Sick building headache } & \multirow{3}{*}{$\begin{array}{c}\text { Crude } \\
\text { odds ratio }\end{array}$} & \multirow{3}{*}{$\begin{array}{c}95 \% \\
\text { confidence } \\
\text { intervals }\end{array}$} & \multirow{3}{*}{$\mathrm{p}$} \\
\hline & \multicolumn{2}{|c|}{$\begin{array}{c}\text { Absent } \\
(\mathrm{N}=122)\end{array}$} & \multicolumn{2}{|c|}{$\begin{array}{c}\text { Present } \\
(\mathrm{N}=36)\end{array}$} & & & \\
\hline & $\mathrm{n}$ & $\%$ & $\mathrm{n}$ & $\%$ & & & \\
\hline \multicolumn{8}{|l|}{ Position $\ldots$} \\
\hline Head of division & 11 & 9.0 & 2 & 5.6 & 1.00 & Referent & \\
\hline Head of department & 19 & 15.6 & 7 & 19.4 & 2.03 & $0.36-11.52$ & 0.426 \\
\hline Head of sub-department & 34 & 27.9 & 10 & 27.8 & 1.62 & $0.31-8.54$ & 0.571 \\
\hline Employee & 58 & 47.5 & 17 & 47.2 & 1.61 & $0.33-7.99$ & 0.559 \\
\hline \multicolumn{8}{|l|}{ Weekly working days } \\
\hline 5 days & 88 & 72.1 & 23 & 63.9 & 1.00 & Referent & 0.340 \\
\hline 6-7 days & 34 & 27.9 & 13 & 36.1 & 1.46 & $0.67-3.21$ & \\
\hline \multicolumn{8}{|l|}{ Daily working hours } \\
\hline 8 hours & 72 & 59.0 & 23 & 63.9 & 1.00 & Referent & \\
\hline 9-10 hours & 47 & 38.5 & 13 & 36.1 & 0.87 & $0.40-1.88$ & 0.715 \\
\hline $11-14$ hours & 3 & 2.5 & 0 & 0 & $N / A^{*}$ & & \\
\hline \multicolumn{8}{|l|}{ Working loads } \\
\hline Mild & 49 & 40.2 & 8 & 22.2 & 1.00 & Referent & \\
\hline Moderate & 63 & 51.6 & 23 & 63.9 & 2.24 & $0.92-5.43$ & 0.075 \\
\hline Heavy & 10 & 8.2 & 5 & 13.9 & 3.06 & $0.83-11.3$ & 0.094 \\
\hline
\end{tabular}

$* \mathrm{~N} / \mathrm{a}=$ Not applicable 
Table 3. Relationship between air movement, gender, breakfast habits and risk of sick building headache

\begin{tabular}{|c|c|c|c|c|c|c|c|}
\hline & \multicolumn{4}{|c|}{ Sick building headache } & \multirow{3}{*}{$\begin{array}{l}\text { Adjusted } \\
\text { odds } \\
\text { ratio* }\end{array}$} & \multirow{3}{*}{$\begin{array}{l}95 \% \\
\text { confidence } \\
\text { intervals }\end{array}$} & \multirow{3}{*}{ p } \\
\hline & \multicolumn{2}{|c|}{$\begin{array}{l}\text { Absent } \\
(\mathrm{N}=122)\end{array}$} & \multicolumn{2}{|c|}{$\begin{array}{l}\text { Present } \\
(\mathrm{N}=36)\end{array}$} & & & \\
\hline & $\mathrm{n}$ & $\%$ & $\mathrm{n}$ & $\%$ & & & \\
\hline \multicolumn{8}{|l|}{ Air movement } \\
\hline Slow & 42 & 34.4 & 20 & 55.6 & 1.00 & Referent & \\
\hline Fast & 80 & 65.6 & 16 & 44.4 & 0.43 & $0.19-0.97$ & 0.043 \\
\hline \multicolumn{8}{|l|}{ Gender } \\
\hline Male & 95 & 77.9 & 20 & 55.6 & 1.00 & Referent & \\
\hline Female & 27 & 22.1 & 16 & 44.4 & 3.64 & $1.52-8.71$ & 0.004 \\
\hline \multicolumn{8}{|c|}{ Working loads } \\
\hline Mild & 49 & 40.2 & 8 & 22.2 & 1.00 & Referent & \\
\hline Moderate & 63 & 51.6 & 23 & 63.9 & 2.51 & $0.95-6.60$ & 0.062 \\
\hline Heavy & 10 & 8.2 & 5 & 13.9 & 4.42 & $1.04-18.86$ & 0.045 \\
\hline \multicolumn{8}{|c|}{ Breakfast habits } \\
\hline Yes & 74 & 60.7 & 30 & 83.3 & 1.00 & Referent & \\
\hline No & 12 & 9.8 & 2 & 5.6 & 0.39 & $0.08-1.93$ & 0.251 \\
\hline Occasionally & 36 & 29.5 & 4 & 11.1 & 0.31 & $0.09-0.98$ & 0.047 \\
\hline
\end{tabular}

* Odds ratio adjusted each other for risk factors on this table.

Our study tried to relate several factors related to SBS headache such as hot working environment, fatigue, stress, job stress/psychosocial, and stress or family/friend problems outside the office. This in accordance with the previous report which emphasized the important role of psychosocial factors, stress, and gender which trigger SBS. ${ }^{4}$ Psychosocial in the job has caused stress, such as work organization, payroll system, behavior problem, employee and supervisor relationship, dissatisfaction against supervisor, and workload that hinder job satisfaction. Psychosocial stress might cause a person to be more susceptible to the risk factors. ${ }^{4,13}$

While a hot working environment could contribute to stress and fatigue among the workers. Previous study on the existence of SBS symptoms along with work stress has predicted that environment pressure and permanent SBS symptoms lead to the growing existing work stress. ${ }^{14}$ In this study, other possibility of SBS headache was caused by other factors such as psychosocial factors within the job, physical factor (dusty environment), and chemical (unpleasant odors at working area and smoke).

In this study, the majority of the employees were male $(71 \%)$, and the remaining of $29 \%$ were females. This study found that females had almost three times higher risk in getting SBS headache than males. This is similar with the previous studies. ${ }^{12,15}$ This may be due to females being often more exposed to cigarette smoke (passive smoker), marital status and number of children, having lower job position in the office, tend to have inferior psychosocial and physical condition than males. Psychosocial factor or stress itself would cause a person to be more susceptible toward risks of SBS headache. On the other hand, male employees had more resistance to cigarette smoke and more often work outside the room.

Job position, type of work, number of working days per week, number of working hours per day and workload were verified not to stimulate the risk of SBS headache. Medium to heavy workload in the univariate analysis results indicated a fair correlation with the risk of a headache. However, in the final model, workload was no longer a threat to the said headache. This may be due to the three dominant factors which are overlapping with the workload such as gender, air movement, and breakfast habit.

Employees who seldom had breakfast would have smaller exposure to SBS headache. The cross tabulation analysis between the breakfast habit and 
the age group demonstrated that employees who seldom had breakfast were mostly of older age, which was probably due to older workers having better self control than the younger ones.

Smoking employees had slightly lower risk of SBS headache $(p=0.171)$ as shown in the univariate table. However, this was not statistically confirmed in the final model. This result was different to the previous study in $1989,{ }^{13}$ which discovered that smoking habit of more than 10 gram tobacco per day correlated significantly with the symptom of . SBS headache compared to those who were not smoking. ${ }^{13}$ The smokers in this survey were probably those who are relatively strong and had better resistance to SBS headache which is probably due to healthy worker effect. $^{16}$

Sick building syndrome is caused by physical, chemical, biological, psychosocial and ergonomic factors. The study office building has reside in the building since 1994 and used the central airconditioning system set up back in 1975. The maintenance of the central AC was not sufficient, which creates an inconvenient working environment. Many employees installed additional fan within their working area.

The measurement of air movement was around of $0.13-0.53 \mathrm{~m} / \mathrm{second}$. Some surveyed spots had reached $\mathrm{l}$ zyond comfort zone of $0.05-0.2 \mathrm{~m} / \mathrm{second}$. The high air movement was probably due to employees often opening the window to reduce the tightness and hot temperature.

Previous study ${ }^{12}$ involving 2,826 employees from 126 offices in 56 government and private office buildings in Singapore (in 1992-1995). The subjects consisted of fifty percent were female employees. The study verified the correlation between the lack of air movement and the emerge of SBS symptoms risk. This may be due to larger sample size and the same number of female and male employees.

The measurement of this study indicated that the temperature ranged between $23.6^{\circ}-31^{\circ} \mathrm{C}$. In Indonesia, the comfort zone temperature ranged between $24^{\circ}-$ $26^{\circ} \mathrm{C}$, which means the temperature in the study office building had exceeded the limit of comfort zone temperature. However, the said temperature was still in compliance with the weighted limit point of working environment temperature as per the recommended by Ministry of Manpower $1978\left(21^{\circ}-30^{\circ} \mathrm{C}\right)$. $^{1,3}$
The measurement of humidity using psyhcrometer showed a range of humidity level between $46.5-81 \%$. Most floors in the studied office (51 measured spots) has humidity less than normal as per the Ministry of Manpower suggestion in 1978. 'However, they were still within the normal zone according to the comfort zone standard of the Westem bibliography $(30-60 \%)$.

Low humidity (dry) may cause irritation in cornea, upper respiratory tract and skin problems. ${ }^{2,17}$ This study demonstrates that temperature and humidity levels were proven not to trigger the risk of SBS headache, which might be caused by the more dominant effect from the air movement factor. This study result was different to the previous ones, ${ }^{12,18}$ which found the relationship between the inconvenient temperature and humidity level to higher risk of SBS headache.

In conclusion, slow air movement and female gender were verified to increase the risk of SBS headache. Therefore, it is recommended to improve the progress of air in order to reduce the risk of SBS headache, especially for female workers.

\section{REFERENCES}

1. Sukar A, Tugaswati T, Athena A, Kasnodihardjo, Heryanto, Hanato M. Sick building syndrome in environment epidemiology perspective. Indon J Public Health $2000 ; 28 ; 3: 260-6$.

2. Morey PR, Singh J. Indoor air quality in non industrial occupational environments. In: Clayton GD, Clayton FE editors. Patty's industrial hygiene and toxicology, General principles. Volume I, part A. $4^{\text {th }}$ ed. New York: John Wiley \& Sons, Inc; 1991. p. 531-94.

3. Holma B. Indoor air pollution. In: Zenz C. Occupational medicine. $3^{\text {rd }}$ ed. NY: Mosby - Year Book; 1997; p. 1067-75.

4. Redlich CA, Sparer J, Cullen MR. Sick-building syndrome. The Lancet 1997April 5;349:1013-6.

5. Citterio A, Sinforiani E, Verri A, Cristina S, Gerosa E, Nappi G. Neurological symptoms of the sick building syndrome: Analysis of a questionnaire. Funct Neuro 1998;13: 225-30.

6. Schwartz BS, Stewart WF, Lipton RB. Lost workdays and decreased work effectiveness associated with headache in the workplace. J Occup Environ Med. 1997;39:320-7.

7. Althouse $\mathrm{AD}$, Tumquist $\mathrm{CH}$, Bracciano $\mathrm{AF}$. Modem refrigeration and air conditioning. $3^{\text {rd }}$ edition. South Holland, Illinois: The Goodheart-Willcox Company, Inc; 1979.

8. Stenberg B, Eriksson N, Höög J, Sundell J, Wall S. The sick building syndrome in office workers. A Case-referent study of personal, psychosocial and building-related risk indicators. Intl J Epidemiol 1994;23:1 190-7. 
9. StataCorp. Stata statistical software: Release 6.0. Texas College station; 2000.

10. Breslow NE, Day NE. Statistica! Methods in Cancer Research. Vol I. The analysis of case-control studies. IARC Sci Publ No.32. Lyon: Intemational Agency for Research on Cancer; 1980.

11. Hosmer DW, Lemeshow S. Applied logistic regression. New York: John Willey \& Sons; 1989.

12. Ooi PL, Goh KT, Phoon MH, Foo SC, Yap HM. Epidemiology of sick building syndrome and its associated risk factors in Singapore. Occup Environ Med 1998;55:188-93

13. Skov P, Valbjøm $\mathrm{O}$ dan Pedersen BV. Influence of personal characteristics, job related factors and psychosocial factors on the sick building syndrome. Scand J Work Environ Health 1989;15:286-95.
14. Apter A, Bracker A, Hodgson M, Didman J, Leung W-Y. Epidemiology of the sick building syndrome. Supplement to J Allergy Clin Immunol 1994;94(2 Pt 2):275-88.

15. Stenberg B, Wall S. Why do women report "Sick building symptoms" more often than men ? Soc Sci Med 1995; 40:491-502.

16. Arrighi HM, Hertz-Piciotto I. The evolving concepts of the healthy worker survivor effect. Epidemiol 1994;5:18696.

17. Calleja AH. Ventilation criteria for non industrial buildings. In: Stellman $\mathrm{M}$, editor. Encyclopedia of occupational health and safety. $4^{\text {th }}$ ed. Geneva: ILO; 1998. p. 45.13-7.

18. Bachmann MO, Myers JE. Influences on Sick building syndrome symptoms in the buildings. Soc Sci Med 1995; $40(2): 245-52$. 